\title{
Applicability of radon emanometry in lithologically discontinuous sites contaminated by organic chemicals
}

\author{
Eduardo De Miguel $^{1} \cdot$ Fernando Barrio-Parra ${ }^{1}$ (D - Javier Elío ${ }^{1,2} \cdot$ Miguel Izquierdo-Díaz $^{1}$ \\ Jerónimo Emilio García-González ${ }^{1} \cdot$ Luis Felipe Mazadiego $^{1} \cdot$ Rafael Medina $^{1}$
}

\begin{abstract}
The applicability of radon $\left({ }^{222} \mathrm{Rn}\right)$ measurements to delineate non-aqueous phase liquids (NAPL) contamination in subsoil is discussed at a site with lithological discontinuities through a blind test. Three alpha spectroscopy monitors were used to measure radon in soil air in a $25,000-\mathrm{m}^{2}$ area, following a regular sampling design with a $20-\mathrm{m}^{2}$ grid. Repeatability and reproducibility of the results were assessed by means of duplicate measurements in six sampling positions. Furthermore, three points not affected by oil spills were sampled to estimate radon background concentration in soil air. Data histograms, Q-Q plots, variograms, and cluster analysis allowed to recognize two data populations, associated with the possible path of a fault and a lithological discontinuity. Even though the concentration of radon in soil air was dominated by this discontinuity, the characterization of the background emanation in each lithological unit allowed to distinguish areas potentially affected by NAPL, thus justifying the application of radon emanometry as a screening technique for the delineation of NAPL plumes in sites with lithological discontinuities.
\end{abstract}

Keywords Non-aqueous phase liquids $\cdot$ Radon $\cdot$ Subsurface contamination $\cdot$ Soil-air $\cdot$ Spatial analysis

\section{Introduction}

Pollution of subsurface soil and groundwater by non-aqueous phase liquids (NAPL) from spills and leaks coming from industrial facilities or landfills has become a global concern as it poses a serious risk to human health and the environment (USEPA 2003; ITRC 2009; USEPA 2015). The delineation of the plume extension is essential in planning the contaminated

Fernando Barrio-Parra fernando.barrio@upm.es

1 Prospecting \& Environment Laboratory (PROMEDIAM), Universidad Politécnica de Madrid, c/ Alenza 4. 28003 Madrid, Spain

2 Geology, School of Natural Sciences, Trinity College Dublin 2, Dublin, Ireland site remediation, as well as in monitoring the evolution and effectiveness of decontamination works. However, field investigations have faced significant challenges to date. Conventionally, these operations have been carried out by drilling and establishing a network of piezometers and wells in order to take samples of soil, groundwater, and NAPL. In the absence of preliminary site assessment studies, intrusive sampling campaigns are high-cost and, even worse, could be unsuccessful for the initial purpose (García-González et al. 2008; Cohen et al. 2016). Alternatively, screening methods have been developed to provide semiquantitative information about the extent of the plume and location of hot spots, i.e., soil gas analysis (e.g., Bishop et al. 1990), geophysical methods (e.g., Ajo-Franklin et al. 2002; Schwartz and Furman 2010, 2011; Schwartz et al. 2012; Sogade et al. 2006), or Rn activity measurements.

Emanometry has been validated as an exploration technique of sites affected by NAPL where there is a homogeneous geospatial subsurface structure (García-González et al. 2008; Schubert et al. 2011; Galhardi and Bonotto 2012; Yoon et al. 2013; Barbosa et al. 2014; De Simone et al. 2017), taking advantage of the existence of natural tracers $-U$ and $\mathrm{Ra}-$ to detect the presence of organic 
Fig. 1 Representation of the sampling grid indicating sampling and background points, and the position of monitoring wells in the study area

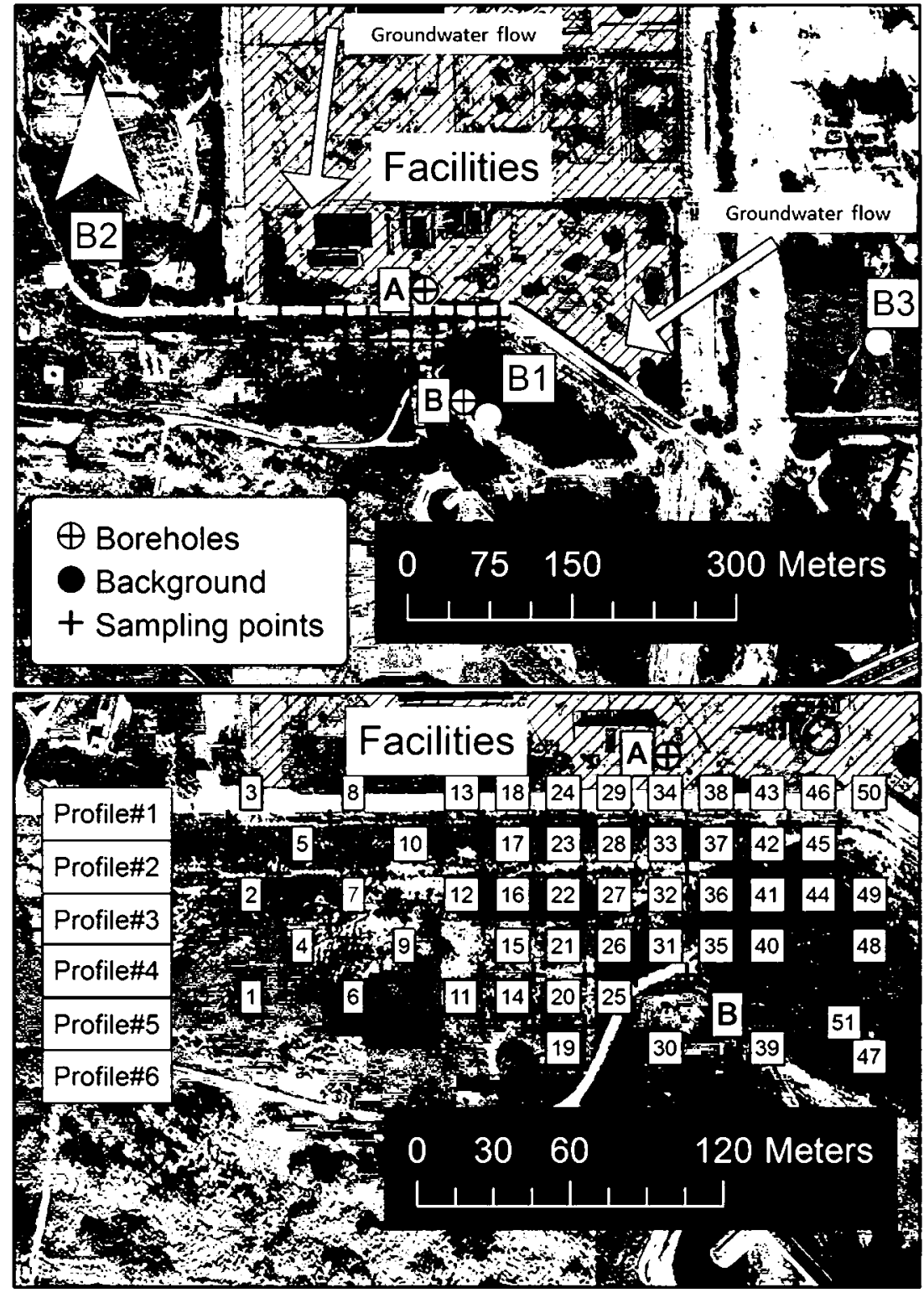

compounds and delineate the extent of subsurface hydrocarbon accumulations. Rn emanometry is based on the surficial reduction of radon $\left({ }^{222} \mathrm{Rn}\right)$ signal due to its preferential distribution in the organic phase (Höhener and Surbeck 2004). In this regard, the accumulation of NAPL in the subsoil acts as geochemical traps for ${ }^{222} \mathrm{Rn}$, due to a different partition coefficient between water, air, and NAPL phases (e.g., De Simone et al. 2015; Schubert et al. 2005, 2007a). Rn solubility in pure organic phases has been extensively studied (e.g., Clever and Battino 1979) and the partition coefficients ( $K_{\mathrm{NAPL} / \mathrm{w}}$ and $K_{\mathrm{NAPL} / \mathrm{air}}$ ) for commercial hydrocarbon mixtures have been experimentally determined (e.g. Schubert et al. 2002a, b, 2007a). As a result, the spatial characterization of radon activity is useful to define areas affected by hydrocarbon spills. A reduced $\mathrm{Rn}$ concentration in soil air with respect to the local background values may be associated with the presence of regions highly saturated with NAPL (e.g., Hunkeler et al. 1997; Semprini et al. 2000; Schubert et al. 2001, 2002a, b, 2005, 2007b; García-González et al. 2008).

Due to its relatively low half-life (3.8 days), ${ }^{222} \mathrm{Rn}$ is expected to have a low mobility in the vadose zone through diffusion processes (Cothern and Smith 1987; Martinelli 1998). However, co-advective transport processes with carrier gases (mainly $\mathrm{CO}_{2}$ ) (Durrance and Gregory 1990; Toutain and Baubron 1999; Etiope and Martinelli 2002; Yang et al. 2003; Etiope et al. 2005; Voltattorni et al. 2009) may be responsible of the ascent of ${ }^{222} \mathrm{Rn}$ from deeper formations (Kristiansson and Malmqvist 1987; Etiope and Lombardi 1996; Etiope and Martinelli 2002) making the "radon-deficit technique" suitable for the detection of NAPL in the vadose and saturated zones (Semprini et al. 2000; De Simone et al. 2017). 
Table 1 Concentration of $\mathrm{Rn}$ in soil air

\begin{tabular}{llllllll}
\hline Point & $\mathrm{Rn}\left(\mathrm{Bq} \mathrm{m}^{-3}\right)$ & Point & $\mathrm{Rn}\left(\mathrm{Bq} \mathrm{m}^{-3}\right)$ & Point & $\mathrm{Rn}\left(\mathrm{Bq} \mathrm{m}^{-3}\right)$ & Point & $\mathrm{Rn}\left(\mathrm{Bq} \mathrm{m}^{-3}\right)$ \\
\hline 1 & 34,470 & 15 & 12,238 & 29 & 43,296 & 43 & 7240 \\
2 & 50,000 & 16 & 19,685 & 30 & 35,570 & 44 & 6285 \\
3 & 16,454 & 17 & 27,604 & 31 & 37,760 & 45 & 19,290 \\
4 & 39,850 & 18 & 31,437 & 32 & 30,945 & 46 & 10,871 \\
5 & 31,732 & 19 & 33,079 & 33 & 20,415 & 47 & 5140 \\
6 & 38,686 & 20 & 14,718 & 34 & 19,439 & 48 & 6235 \\
7 & 26,237 & 21 & 30,097 & 35 & 12,888 & 49 & 5535 \\
8 & 24,425 & 22 & 32,933 & 36 & 19,082 & 50 & 13,447 \\
9 & 26,435 & 23 & 50,000 & 37 & 27,319 & $51(\mathrm{~B} 1)$ & 4362 \\
10 & 16,870 & 24 & 22,041 & 38 & 13,031 & $\mathrm{~B} 2$ & 25,524 \\
11 & 27,969 & 25 & 30,485 & 39 & 5763 & $\mathrm{~B} 3$ & 4063 \\
12 & 41,073 & 26 & 32,315 & 40 & 8758 & & \\
13 & 50,000 & 27 & 36,992 & 41 & 5957 & & \\
14 & 43,744 & 28 & 50,000 & 42 & 7084 & & \\
\hline
\end{tabular}

In fractured zones, there is an intensification of the $R n$ signal due to the increase in soil permeability. In fact, the $\mathrm{Rn}$ emanometry has been amply used in the characterization of fractured systems (e.g., Fu et al. 2005, 2008; Gascoyne et al. 1993; Ioannides et al. 2003; Walia et al. 2005). Abrupt changes in soil-air Rn concentrations may also occur in these areas as a result of the variation in the lithological composition on both sides of the fault, with different contents of $U$ and Ra in the geological matrix (e.g., Gascoyne et al. 1993; King et al. 1996; Moussa and A.G.M. EA 2003). Thus, lithological discontinuities may generate misinterpretations of the NAPL plume delineation (Schubert et al. 2002a; Barbosa et al. 2014) especially when the age of the spill is great enough to result in a significant loss of volatile compounds in the subsurface.

Following the above discussion, the objectives of the present study are (1) to develop and apply a data analysis methodology to spatially associate radon data to lithological units and (2) to discuss the applicability of emanometry for delineating NAPL plumes at sites with a priori unknown lithological spatial variations.

\section{Materials and methods}

The sampling campaign was carried out using three alpha spectroscopy monitors (two SARAD® RTM-2100 and one RTM-2010 models). Soil air was aspirated through hollow rods buried $75-100 \mathrm{~cm}$ in the subsoil in order to avoid the influence of atmospheric variables (García-González et al. 2008). ${ }^{222} \mathrm{Rn}$ measurements were performed by setting the devices in "Fast" mode (only the emissions of alpha particles from the decay of ${ }^{218}$ Po are considered for the quantification of ${ }^{222} \mathrm{Rn}$ concentration in $\mathrm{Bq} \mathrm{m}{ }^{-3}$ ) with integration times of
$10 \mathrm{~min}$ and a recording duration of $40 \mathrm{~min}$. The analytical uncertainties associated with the Rn measurement procedure was approximately $10 \%$ and the instrumental detection limit was $1 \mathrm{KBq} \mathrm{m}^{-3}$ (SARAD 2002). If radon levels in the sample reached $50,000 \mathrm{~Bq} \mathrm{~m}^{-3}$ before the end of the 40 -min measure interval, sampling was stopped and a value of $50,000 \mathrm{~Bq} \mathrm{~m}^{-3}$ was assigned to these points. After each measurement, the internal pump was operated at high flow for $20-30 \mathrm{~min}$ to clean the ionization chamber before the next sample. As far as it was possible, the determinations were carried out

Table 2 Results of Rn measurement repeatability assessment

\begin{tabular}{lllll}
\hline Point & Instrument & Model & Rn $\left(\mathrm{Bq} \mathrm{m}^{-3}\right)$ & RSD (\%) \\
\hline 3 & 1 & RTM 2100 & 14,757 & 15 \\
& 1 & RTM 2 100 & 18,150 & \\
24 & 2 & RTM 2010 & 22,477 & 3 \\
& 1 & RTM 2100 & 21,605 & \\
27 & 2 & RTM 2010 & 34,257 & 10 \\
& 1 & RTM 2100 & 39,726 & \\
29 & 2 & RTM 2010 & 36,592 & 22 \\
& 1 & RTM 2100 & 50,000 & \\
37 & 3 & RTM 2100 & 26,878 & 2 \\
& 1 & RTM 2100 & 27,760 & \\
45 & 1 & RTM 2100 & 19,614 & 2 \\
& 1 & RTM 2100 & 18,965 & \\
B1 & 3 & RTM 2100 & 4635 & 6 \\
& 2 & RTM 2010 & 4358 & \\
B2 & 1 & RTM 2100 & 4093 & \\
& 3 & RTM 2100 & 27,297 & 20 \\
& 2 & RTM 2010 & 19,777 & \\
B3 & 1 & RTM 2100 & 29,499 & \\
& 3 & RTM 2100 & 4218 & 5 \\
\hline
\end{tabular}


Profile No. 1

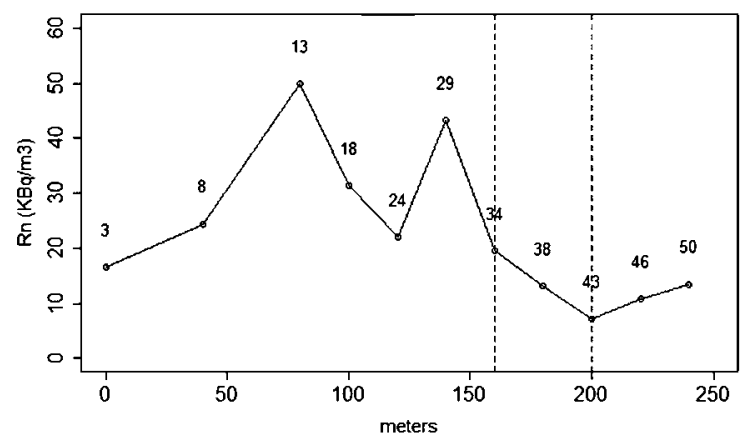

Profile No. 3

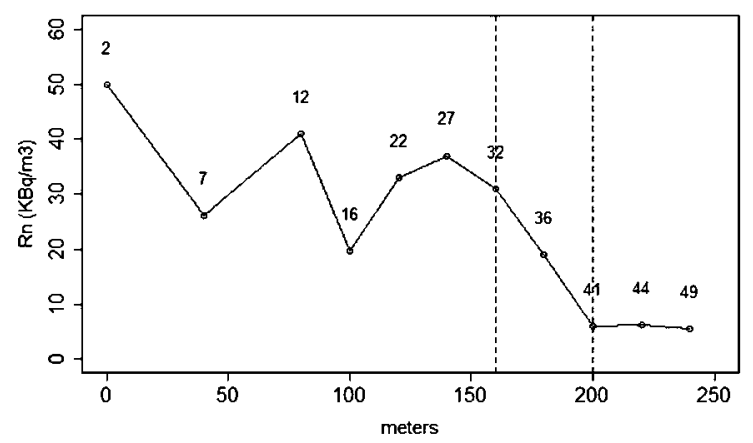

Profile No. 5

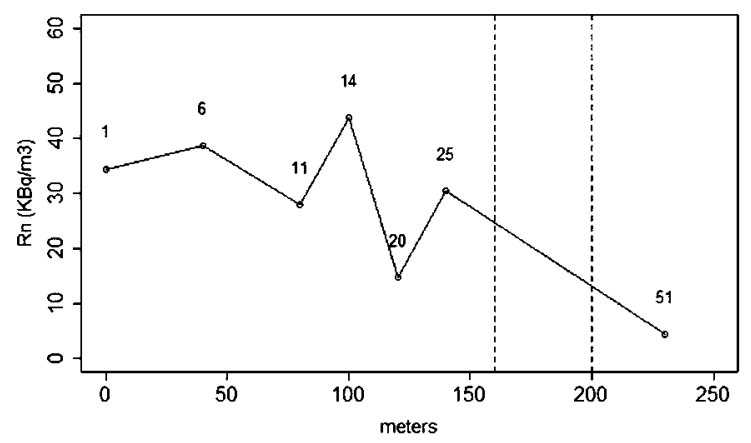

Profile No. 2

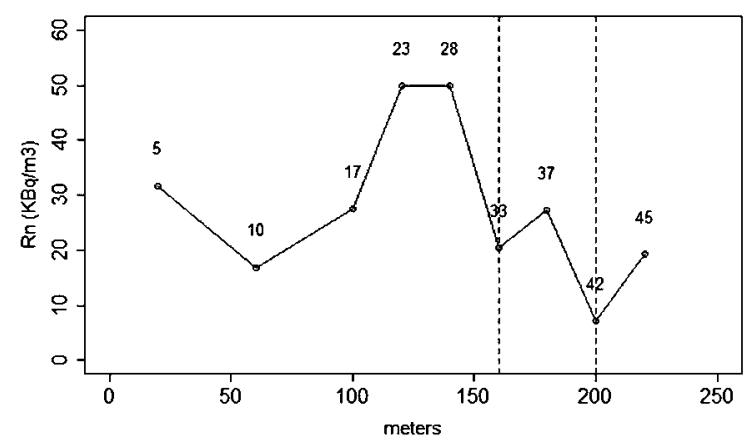

Profile No. 4

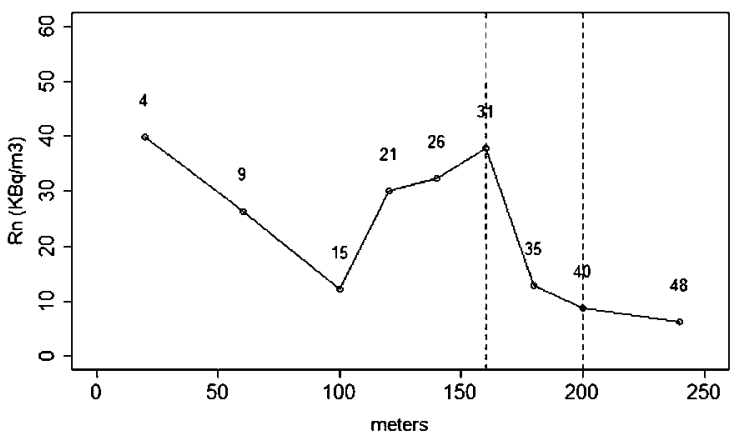

Profile No. 6

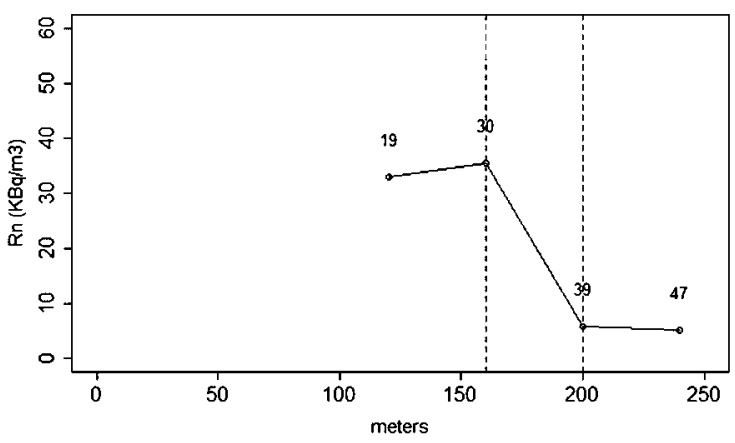

Fig. 2 W-E Rn concentration profiles $\left(\mathrm{KBq} \mathrm{m}^{-3}\right)$. Labels indicate sampling point

following a sequence from low to high radon concentrations in soil air to shorten cleaning times.

All $\mathrm{Rn}$ activity determinations were made under similar conditions of soil pore water saturation. In addition to $\mathrm{Rn}$ concentrations, other environmental variables were also recorded at the same time, i.e., atmospheric temperature, barometric pressure, relative humidity, and wind speed. Concentrations of volatile organic compounds (VOCs) in soil air were measured using a photoionization detector (PID, Industrial Scientific) making use of the same sampling grid.

The study area is located just south of a petrochemical plant built in 1972 and approximately $3.5 \mathrm{~km}$ from the Portuguese west coast line (specific location and coordinates are omitted because of a confidentiality agreement). The area is affected by a light NAPL spill in the vadose zone, but no additional information about the extent or composition of the plume was provided. The complex is situated on a sequence of sedimentary materials from the Paleozoic to the Holocene, mostly separated by a discordant contact between each other (Chambel et al. 2010). An outcrop of limestones and clays from the Miocene, corresponding to the transition between the sea and the river basin (located about $5.6 \mathrm{~km}$ to the south), is found in the southern part of the site. To the east, there is a fault with a North-West orientation that is active at present (Cabral and Ribeiro 1988). In order to develop a blind experiment, the information about the fracture system associated with this fault was not provided until the field campaign was finished, and only then was this data used to validate the results.

A systematic sampling grid was adopted, with NS and EW transects every $20 \mathrm{~m}$, covering an area of approximately $25,000 \mathrm{~m}^{2}$ (Fig. 1). After the first east-west and north-south profiles were completed, measurements along successive transects were initially taken at 40-m intervals (one node out of 
Fig. 3 a Histogram of Rn activity in field samples (solid line represents fitted probability density). b Q-Q plot. c variogram of the West zone. $d$ variogram of the East zone (a)

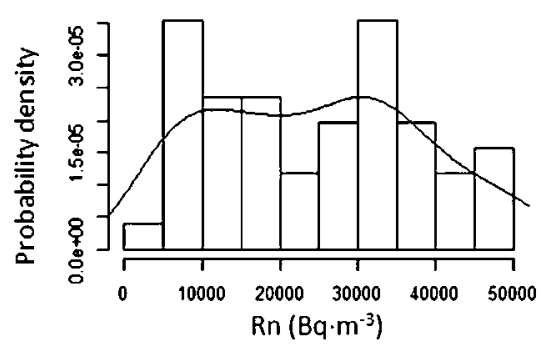

(c)

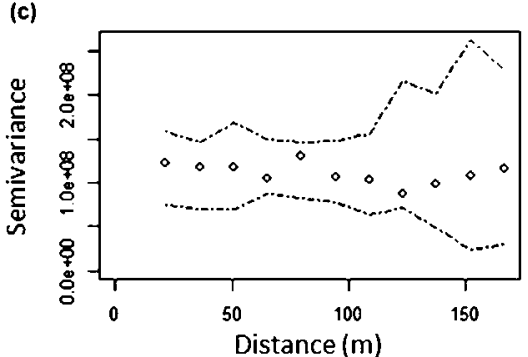

(b)

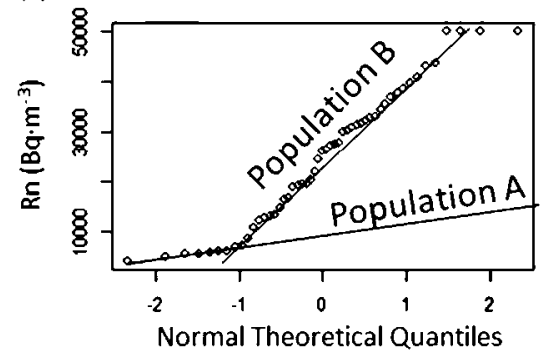

(d)

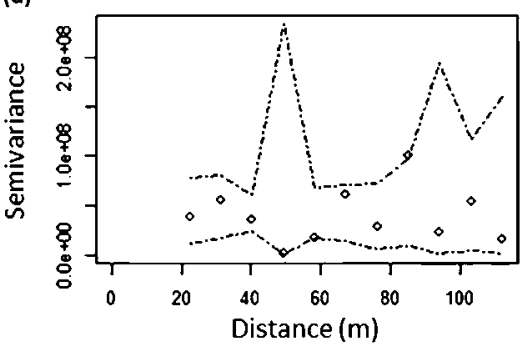

two of the grid). The remaining grid locations were sampled following an adaptive approach, based on previously obtained values. All measurements in each profile were performed with a single instrument. Radon measurements were duplicated in six sampling points of the grid to assess the repeatability and reproducibility of the results. Once the initial results were obtained and interpreted, two new NS profiles were added at the eastern end of the original grid, while the two westernmost profiles were discarded, for a total of 50 sampling points and 68 radon-in-soil-air determinations. Background levels of Rn in soil air were determined in triplicate at three points located in areas which presumably were not affected by the spill: One was positioned northwest of the grid (B2), another to the east (B3), and the last one to the southeast (B1).

Fig. 4 Surface map of Rn activity

$\left(\mathrm{Bq} \mathrm{m}{ }^{-3}\right.$ ) (maximum actual measurement, $50 \mathrm{KBq} \mathrm{m}^{-3}$; values above that threshold are interpolated values)
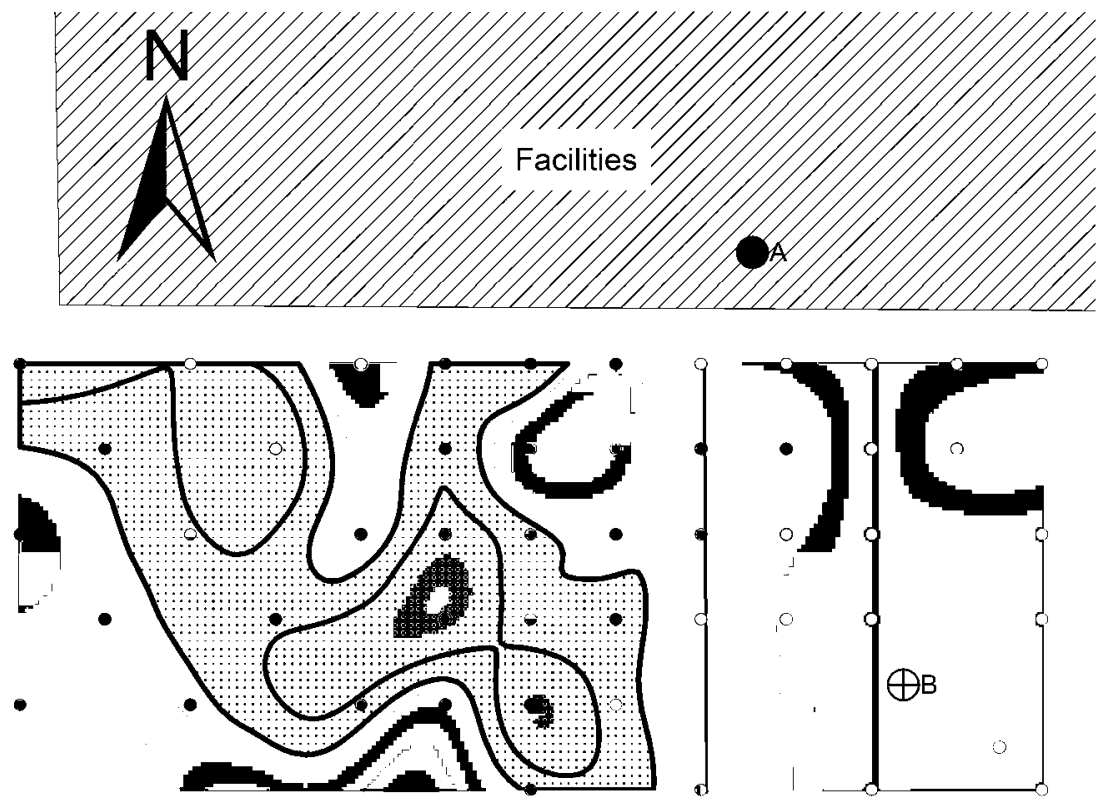

- Cluster 1

- Cluster 2

-Fringe

ĐBoreholes
$\mathrm{KBq} / \mathrm{m}^{\wedge} \mathbf{3}$

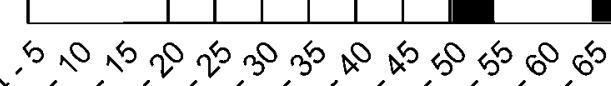

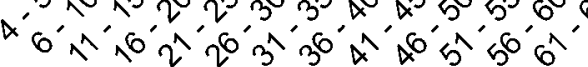




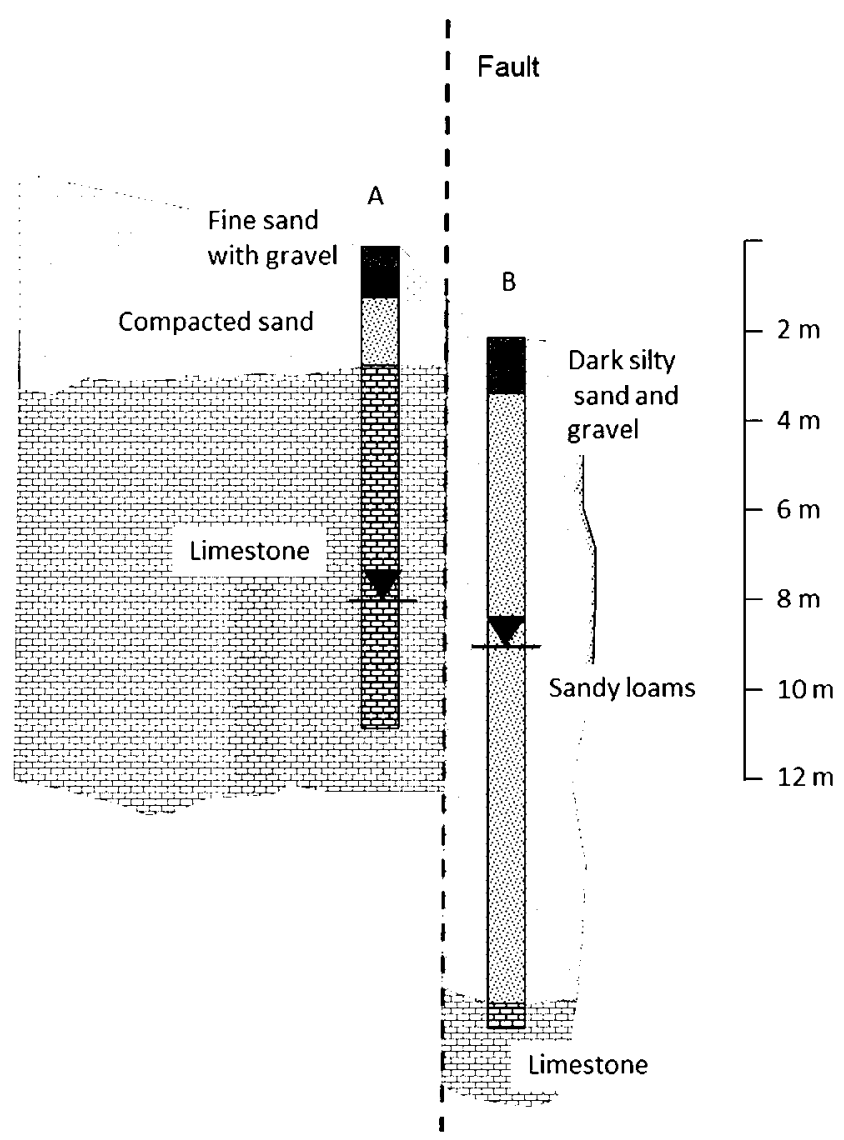

Fig. 5 Lithological sequence obtained from boreholes A and B

To determine whether the acquired data belong to one or two different populations (associated with two different lithological compositions or the presence of a fault), histograms and Q-Q plots were constructed and analyzed. A Q-Q plot is a graphical method to assess the differences between the probability distribution function of a sample and a theoretical distribution. It can be employed to compare the inferred distribution of two sets of observations with different sample size. Variography was used to assess the spatial relationship between measurements of Rn activity. Statistical and geostatistical analysis of data was carried out with the GeoR (Ribeiro and Diggle 2015) and Stats libraries in the R environment ( $R$ Development Core Team 2015). The spatial delineation of two populations of data was of special interest because it could indicate the presence of a lithological discontinuity or a fault. Spatial data clustering was investigated with the Grouping Analysis tool in ArcGIS 10.1 (ESRI Developer Network 2016).

\section{Results}

Determinations of Rn activity in the sampled soil air are summarized in Table 1. Results ranged between a minimum of $5140 \mathrm{~Bq} \mathrm{~m}^{-3}$ (point 47) and values above $50,000 \mathrm{~Bq} \mathrm{~m}^{-3}$ (points 2, 13, 23, 28). To the West of the study area, the background value (B2) was approximately $25,000 \mathrm{~Bq} \mathrm{~m}^{-3}$, while in the East, background Rn activity decreased to values around $4000 \mathrm{~Bq} \mathrm{~m}^{-3}$ (B3). VOC determinations did not show significant differences with atmospheric air anywhere within the sampling grid, and therefore could not be used as an indicator of NAPL pollution.

To assess the repeatability of the records, replicates of Rn determinations were carried out using the three monitoring instruments in four points of the sampling grid and in the three background points in different days (Table 2). To assess the repeatability of the most frequently used instrument (Instrument 1), measurements were replicated in two sampling points (points 3 and 45). The relative standard deviation (RSD) between replicates with different instruments varied between 2 and 20\%. The RSD of Instrument 1 varied between 2 and $15 \%$. These results validate the joint interpretation of all Rn measurements, independently of the instrument or date of the measurement.

\section{Discussion}

The remarkable difference between background Rn emanation to the West $\left(25,000 \mathrm{~Bq} \mathrm{~m}^{-3}\right)$ and East $\left(4000 \mathrm{~Bq} \mathrm{~m}^{-3}\right)$ of the industrial plant suggests a change in the lithological characteristics of the subsurface matrix, with disparate Rn emanation values due the presence of a lithological discontinuity.

Figure 2 shows the Rn activity results grouped by WestEast profiles. Profile No. 1 was the northern-most one, placed immediately to the south of the facilities, and the rest of profiles were sequentially located every $20 \mathrm{~m}$ southwards (Fig. 1). The most notable feature, observable in all six profiles, is the sharp decline in Rn concentration in the 160-200-m fringe (marked with dashed blue lines). Rn concentrations to the west of this fringe fluctuate between 15,000 and $50,000 \mathrm{~Bq} \mathrm{~m}^{-3}$ while in the east, they reach relatively stable values near the background level (B1-B3; 4000$5000 \mathrm{~Bq} \mathrm{~m}^{-3}$ ).

The histogram, normal Q-Q plot, and variograms of the data of Rn concentration in soil air are shown in Fig. 3. The histogram shows a bimodal distribution (Fig. 3a) and the Q-Q plot (Fig. 3b) suggests the existence of two populations of Rn activity data. These populations are spatially separated by the $160-200-\mathrm{m}$ fringe (Figs. 2 and 4 ). In a separate study of the spatial relationship within each population (Fig. 3c, d), it was observed that the experimental variograms (points) fell inside the envelope of all variograms generated by random permutation of the observations (dashed lines). For a statistically significant spatial relationship, the actual semivariance should lie outside these random bounds at a specific distance (range). The absence of a significant semivariance at any 
distance indicates a spatially random process, with no spatial correlation between the different concentrations of radon in soil air (Bivand et al. 2008).

This lack of significant variograms precludes the construction of surface and isovalues maps employing geostatistical models (i.e., Kriging). Consequently, a Spline interpolation (ESRI Developer Network 2007) was chosen for a 2-D representation of Rn concentration (Fig. 4). The lateral discontinuity was confirmed with a spatial cluster analysis (ESRI Developer Network 2016) which resulted in a grouping of all samples in two populations again separated by the discontinuity fringe (red [Cluster 1] and blue [Cluster 2] dots in Fig. 4). Rn activity levels in the eastern section of the study area were below $10,000 \mathrm{~Bq} \mathrm{~m}^{-3}$, except in the North East boundary, where values of $19,000 \mathrm{~Bq} \mathrm{~m}^{-3}$ were reached. In the western section, Rn determinations were highly variable, but consistently higher than in the East.

In the absence of lateral changes in the mineralogical matrix in the subsoil or far from any preferential pathways of Rn migration, the clear decrease in the Rn activity in the eastern third of the sampled area could be interpreted as a manifestation of the presence of NAPL in the unsaturated zone or the aquifer. However, the value registered at B3 (located sideways and not downflow with respect to the facilities area, where the source of contamination is located, and thus far from any possible NAPL sources) was in the same order of magnitude as the concentrations in the sampling points of the eastern third of the sampled grid. If a pollutant plume associated with low concentrations of Rn were indeed present, it should then extend at least to the $\mathrm{B} 3$ position, something that seems highly unlikely.

The sharp decrease in Rn concentrations is more probably due to a lateral discontinuity in the subsurface materials. This hypothesis is validated with information on the lithological profile of the area derived from drilling cores retrieved in the study zone (Fig. 5). The interpretation of these data seems to indicate the presence of a fault in that area. Therefore, $\mathrm{Rn}$ emanation rates and resistivity to gas flow are different on each side of the discontinuity, and, as a consequence, radon background concentrations vary significantly between both areas. Consequently, the interpretation of Rn levels should be done separately for each geologic matrix, each with different natural Rn emanation levels and different air permeabilities, which result in two different natural backgrounds, i.e., $25,000 \mathrm{~Bq} \mathrm{~m} \mathrm{~m}^{-3}$ in the west zone (B2) and $4000 \mathrm{~Bq} \mathrm{~m}^{-3}$ in the east zone (B3).

In the western area, there were records below the background value. Dotted areas in Fig. 4 show zones with Rn activity below the mean $\mathrm{B} 2$ value of $25,000 \mathrm{~Bq} \mathrm{~m}^{-3}$, within red contours, and below the maximum $\mathrm{B} 2$ value plus 1 standard deviation (Table 2) of $35,000 \mathrm{~Bq} \mathrm{~m}^{-3}$, within black contours, that could be interpreted as the manifestation of a process of contamination in depth. These areas were flanked by measurements clearly above the local background, and even exceeding $50,000 \mathrm{~Bq} \mathrm{~m}^{-3}$. The occurrence of these maxima can be explained if they are associated with the presence of a fracture system in the subsoil and if these fractures constitute a preferential pathway for gas migration, enhancing the coadvective transport processes with the flow of $\mathrm{CO}_{2}$ and $\mathrm{CH}_{4}$ (Durrance and Gregory 1990; Toutain and Baubron 1999; Etiope and Martinelli 2002; Yang et al. 2003; Etiope et al. 2005; Voltattorni et al. 2009). Another possible interpretation for those high values may be the formation of a radon emanation halo around a hydrocarbon pool. Previous works (e.g., E Q Barbosa et al. 2014; García-González et al. 2008) have also obtained Rn activity measurements higher than the local background around an NAPL-affected area. This may occur by the accumulation of precipitated $U$ at the edges of the hydrocarbon plume that begins to disintegrate and to produce $\mathrm{Rn}$. This process has been documented in geochemical prospecting for petroleum deposits (e.g., Bell 1960; Mazadiego 1994; Morse et al. 1982) where the presence of hydrocarbons in the subsurface produces a reducing environment around the area where they accumulate. The reducing environment causes the uranyl ion $\left(\mathrm{UO}_{2}{ }^{2+}\right)$ dissolved in groundwater to reduce from a $(+6)$ to a $(+4)$ oxidation state and to precipitate as $\mathrm{UO}_{2}$ around the pool of hydrocarbons. $\mathrm{U}(+6)$ has a strong affinity for organics with high molecular weight, being able to form complex under acidic to alkaline $\mathrm{pH}$ conditions retaining it migration to the aqueous phase (Zavodska et al. 2008). Uranium speciation strongly depends on $\mathrm{pH}$ and oxidation/reduction (redox) conditions (Szecsody et al. 1998; Zavodska et al. 2008; Kim et al. 2009). However, uncertainties about the kinetics that control these $U$ precipitation processes make it difficult to assess its importance in the formation of a Rn halo around NAPL-affected areas. For example, Nakashima et al. (1999) studied the reduction kinetics of uranyl cations to uraninite in aqueous solution by two lignites under diagenetic or hydrothermal conditions. They estimated the half-life of $U$ precipitation as a function of temperature. Under modest thermal conditions $\left(200-100^{\circ} \mathrm{C}\right)$, the half-life of $\mathrm{U}$ precipitation is in the order of $3 \mathrm{~h}$ to 1 year, 340 years for radioactive waste repositories $\left(50^{\circ} \mathrm{C}\right)$, and $10^{4}$ to $10^{5}$ years at the Earth's surface $\left(25-4^{\circ} \mathrm{C}\right)$. Since the geothermal gradient in the study area is not very high, it is unlikely that uranium precipitation was the cause of the large increase in soil-air radon concentrations. However, more research should be undertaken in order to better understand the effect of uranium precipitation in oil spills and the possible associated radon anomalies over time.

\section{Conclusions}

This study has tested the applicability of Rn emanometry to delineate NAPL affection in the subsoil of a site with non- 
uniform lithology. Radon $\left({ }^{222} \mathrm{Rn}\right)$ concentrations in soil air were dominated by a fault and a lithological discontinuity. The results showed a clear decrease in the concentration of $\mathrm{Rn}$ on the eastern section of the sampled area which seems to respond to a sharp lateral discontinuity in the mineralogical properties of the matrix subsurface rather than a possible NAPL contamination process. On the other hand, radon concentrations lower than the local background were found in the western sector, suggesting that this area could actually be affected by NAPL contamination. Radon emanation above background levels were also observed in the western sector. The most plausible explanation for these observations is the presence of a fractured system that enhances $\mathrm{Rn}$ migration through co-advective transport.

The data analysis undertaken in this study has allowed to identify two different radon-in-soil-air data populations, showing a spatial clustering associated with the lithological discontinuity. The information from two boreholes confirmed the presence of these two zones, separated by a fault. In this regard, the study of the radon concentration in soil air has been useful to characterize the lithological discontinuity and to identify the fault.

The effective implementation of the application of Rn activity determinations as a screening technique for the delineation of NAPL plumes in sites with lithological discontinuities requires (i) the correct characterization of the radon natural background variations due to the different lithologies and (ii) a proper statistical/geostatistical analysis of the radon measurements.

Funding information This study was funded through the CARESOILCM (S2013/MAE-2739) and CAREDENSE/DENSOIL (CTM201677151-C2-2-R) research grants of the Regional Government of Madrid (Comunidad de Madrid) and the Spanish Ministry of Economy, Industry and Competitiveness, respectively. J Elío was supported by the Irish Research Council (IRC), through the Enterprise Partnership Scheme Postdoctoral Fellowship 2015 [EPSPD/2015/46], and co-financed by the Geological Survey of Ireland (GSI).

\section{References}

Ajo-Franklin J. B., Geller J. T., Majer E. L., et al (2002) Integrated geophysical characterization of a NAPL-contaminated site using borehole and laboratory measurements. Am Geophys Union

Barbosa EQQ, Galhardi JA, Bonotto DMM (2014) The use of radon (Rn222) and volatile organic compounds in monitoring soil gas to localize NAPL contamination at a gas station in Rio Claro, São Paulo State, Brazil. Radiat Meas 66:1-4. https://doi.org/10.1016/j. radmeas.2014.04.024

Bell KG (1960) Uranium and other trace elements in petroleums and rock asphalts. Geol Surv Prof Pap 356

Bishop PK, Burston MW, Lerner DN, Eastwood PR (1990) Soil gas surveying of chlorinated solvents in relation to groundwater pollution studies. Q J Eng Geol Hydrogeol 23:255-265. https://oi.org/ 10.1144/GSL.QJEG.1990.023.03.07
Bivand R, Pebesma EJ, Gópmez-Rubio V (2008) Applied spatial data analysis with R. Springer

Cabral J, Ribeiro A (1988) Carta Neotectónica de Portugal continental. Escala 1/1.000.000. LNEG - Laboratório Nacional de Energia e Geologia, I.P. http://www.lneg.pt

Chambel A, Monteiro JP, Nunes LM et al (2010) Hydrogeological study of contamination in the Aquifer System of Sines, South Portugal. In: Zuber A, Kania J, Kmiecik E (eds) XXXVIII IAH Congress. University of Silesia Press, Krakow, pp 2190-2195

Clever HL, Battino R (1979) Krypton, xenon, and radon: gas solubilities. Pergamon Press, Oxford, pp 357

Cohen GJV, Jousse F, Luze N, Höhener P, Atteia O (2016) LNAPL source zone delineation using soil gases in a heterogeneous siltysand aquifer. J Contam Hydrol 192:20-34. https://doi.org/10.1016/j. jconhyd.2016.06.001

Cothern R, Smith JE (1987) Environmental radon. In: Environmental science research, volume 35. Plenum Press, New York

De Simone G, Galli G, Lucchetti C, Tuccimei P (2015) Using natural radon as a tracer of gasoline contamination. Procedia Earth Planet Sci 13:104-107. https://doi.org/10.1016/j.proeps.2015.07.025

De Simone G, Lucchetti C, Pompilj F et al (2017) Soil radon survey to assess NAPL contamination from an ancient spill. Do kerosene vapors affect radon partition? J Environ Radioact 171:138-147. https://doi.org/10.1016/j.jenvrad.2017.02.014

Durrance EM, Gregory GR (1990) Helium and radon transport mechanisms in hydrothermal circulation systems of Southwest England. Geochemistry Gaseous Elem Compd 92(B12):12567-12586. https://doi.org/10.1029/JB092iB12p12567

ESRI Developer Network (2007) Applying a spline interpolation. In ArcGIS 9.2 Deskt. Help. http://webhelp.esri.com/arcgisdesktop/9. $2 /$ index.cfm? TopicName=Applying_a_spline_interpolation. Accessed 5 May 2016

ESRI Developer Network (2016) How grouping analysis works. In: ArcGIS Pro ArcGIS Deskt. http://pro.arcgis.com/en/pro-app/toolreference/spatial-statistics/how-grouping-analysis-works.htm. Accessed 7 May 2016

Etiope G, Lombardi S (1996) Laboratory simulation of geogas microbubble flow. Environ Geol 27:226-232. https://doi.org/10. 1007/BF00770436

Etiope G, Martinelli G (2002) Migration of carrier and trace gases in the geosphere: an overview. Phys Earth Planet Inter 129:185-204. https://doi.org/10.1016/S0031-9201(01)00292-8

Etiope G, Guerra M, Raschi A (2005) Carbon dioxide and radon geohazards over a gas-bearing fault in the Siena Graben (Central Italy). Terr Atmos Ocean Sci 16:885-896. https://doi.org/10.3319/ TAO.2005.16.4.885(GIG)

Fu C-C, Yang TF, Vivek Walia A, Chen C-H (2005) Reconnaissance of soil gas composition over the buried fault and fracture zone in southern Taiwan. Geochem J 39:427-439

Fu CC, Yang TF, Du J et al (2008) Variations of helium and radon concentrations in soil gases from an active fault zone in southern Taiwan. Radiat Meas 43:348-352. https://doi.org/10.1016/j. radmeas.2008.03.035

Galhardi JA, Bonotto DM (2012) Radon in groundwater contaminated by dissolved hydrocarbons in Santa Barbara d'Oeste, Sao Paulo State, Brazil. Appl Radiat Isot 70:2507-2515. https://doi.org/10.1016/j. apradiso.2012.06.029

García-González JE, Ortega MF, Chacón E, Mazadiego LF, Miguel ED (2008) Field validation of radon monitoring as a screening methodology for NAPL-contaminated sites. Appl Geochem 23:2753-2758. https://doi.org/10.1016/j.apgeochem.2008.06.020

Gascoyne M, Wuschke DM, Durrance EM (1993) Fracture detection and groundwater flow characterization using $\mathrm{He}$ and $\mathrm{Rn}$ in soil gases, Manitoba, Canada. Appl Geochem 8:223-233. https://doi.org/10. 1016/0883-2927(93)90037-H 
Höhener P, Surbeck H (2004) Radon-222 as a tracer for nonaqueous phase liquid in the vadose zone. Vadose Zo J 3:1276. https://doi. org $/ 10.2136 /$ vzj2004.1276

Hunkeler D, Hoehn E, Höhener P, Zeyer J (1997) 222 Rn as a partitioning tracer to detect diesel fuel contamination in aquifers: laboratory study and field observations. Environ Sci Technol 31:3180-3187. https://doi.org/10.1021/es970163w

Ioannides K, Papachristodoulou C, Stamoulis K, Karamanis D, Pavlides S, Chatzipetros A, Karakala E (2003) Soil gas radon: a tool for exploring active fault zones. Appl Radiat Isot 59:205-2013. https://doi.org/10.1016/S0969-8043(03)00164-7

ITRC (2009) Evaluating LNAPL remedial technologies for achieving project goals. LNAPL-2. Interstate Technology \& Regulatory Council, LNAPLs Team, Washington, D.C. www.itrcweb.org

Kim K-W, Kim Y-H, Lee S-Y, Lee JW, Joe KS, Lee EH, Kim JS, Song K, Song KC (2009) Precipitation characteristics of uranyl ions at different $\mathrm{pHs}$ depending on the presence of carbonate ions and hydrogen peroxide. Environ Sci Technol 43:2355-2361. https://oi.org/ 10.1021/es802951b

King C-Y, King B-S, Evans WC, Zhang W (1996) Spatial radon anomalies on active faults in California. Appl Geochem 11(4):497-510. https://doi.org/10.1016/0883-2927(96)00003-0

Kristiansson K, Malmqvist L (1987) Trace elements in the geogas and their relation to bedrock composition. Geoexploration 24:517-534. https://doi.org/10.1016/0016-7142(87)90019-6

Martinelli G (1998) Gas geochemistry and 222Rn migration process. Radiat Prot Dosim 78:77-82. https://doi.org/10.1093/ oxfordjournals.rpd.a032338

Mazadiego LF (1994) Desarrollo de una metodología para la prospección geoquímica en superficie de combustibles fósiles. $\mathrm{PhD}$ Thesis, Universidad Politécnica de Madrid. Available at: http:/oa.upm.es/ $1287 /$

Morse JG, Rana MH, Morse L (1982) Radon mapping aas indicators of subsurface oil and gas. Oil Gas J 80:227-246

Moussa MM, A.G.M. EA (2003) Soil radon surrey for tracing active fault: a case study along Qena-Safaga road, Easter Desert, Egypt. Radiat Meas 37:211-216

Nakashima S, Disnar J-R, Perruchot A (1999) Precipitation kinetics of uranium by sedimentary organic matter under diagenetic and hydrothermal conditions. Econ Geol 94:993-1006. https://doi.org/10. 2113/gsecongeo.94.7.993

R Development Core Team (2015) R: a language and environment for statistical computing. https://www.r-project.org/

Ribeiro PJJ, Diggle PJ (2015) geoR: analysis of geostatistical data. R package version 1:7-5.1. https://cran.r-project.org/web/packages/ geoR/index.htm

SARAD (2002) Operation manual RTM 2100 (Radon/Thoron monitor). https://www.sarad.de/

Schubert M, Freyer K, Treutler HC, Weiß H (2001) Using the soil gas radon as an indicator for ground contamination by non-aqueous phase-liquids. J Soils Sediments 1:217-222. https://doi.org/10. 1007/BF02987728

Schubert M, Freyer K, Treutler HC, Weiss H (2002a) Using radon-222 in soil gas as an indicator of subsurface contamination by non-aqueous phase-liquid (NAPLs). Geofis Int 41:433-437

Schubert M, Schultz H, Schulz H (2002b) Diumal radon variations in the upper soil layers and at the soil-air Interface related to meteorological parameters. Health Phys 83:91-96. https://doi.org/10.1097/ 00004032-200207000-00010

Schubert M, Peña P, Balcázar M, Meissner R, Lopez A, Flores JH (2005) Determination of radon distribution patterns in the upper soil as a tool for the localization of subsurface NAPL contamination. Radia Meas 40:633-637. https://doi.org/10.1016/j.radmeas.2005.04.020

Schubert M, Lehmann K, Paschke A (2007a) Determination of radon partition coefficients between water and organic liquids and their utilization for the assessment of subsurface NAPL contamination. Sci Total Environ 376:306-316. https://doi.org/10.1016/j.scitotenv. 2006.12 .050

Schubert M, Paschke A, Lau S, Geyer W, Knöller K (2007b) Radon as a naturally occurring tracer for the assessment of residual NAPL contamination of aquifers. Environ Pollut 145:920-927. https://doi.org/ 10.1016/j.envpol.2006.04.029

Schubert M, Schmidt A, Muller K, Weiss H (2011) Using radon-222 as indicator for the evaluation of the efficiency of groundwater remediation by in situ air sparging. J Environ Radioact 102:193-199. https://doi.org/10.1016/j.jenvrad.2010.11.012

Schwartz N, Furman A (2010) Electrical properties of NAPL contaminated unsaturated soil. In: EGU General Assembly Conference. $p$ 14870

Schwartz N, Furman A (2011) Electrical properties of NAPL contaminated soils: final report submitted to the Grand Water Research Institute. 1-16

Schwartz N, Huisman JA, Furman A (2012) The effect of NAPL on the electrical properties of unsaturated porous media. Geophys $\mathbf{J}$ Int 188(3):1007-1011. https://doi.org/10.1111/j.1365-246X.2011. 05332.x

Semprini L, Hopkins OS, Tasker BR (2000) Laboratory, field and modeling studies of radon-222 as a natural tracer for monitoring NAPL contamination. Transp Porous Media 38:223-240

Sogade JA, Scira-Scappuzzo F, Vichabian Y et al (2006) Inducedpolarization detection and mapping of contaminant plumes. Geophysics 71:B75-B84. https://doi.org/10.1190/1.2196873

Szecsody JE, Cantrell KJ, Krupka KM et al (1998) Uranium mobility during in situ redox manipulation of the 100 areas of the Handford Site. PNNL-12048, Pacific Northwest National Laboratory, Richland, $\mathrm{p} 41$

Toutain J-P, Baubron J-C (1999) Gas geochemistry and seismotectonics: a review. Tectonophysics 304:1-27

USEPA (2003) The DNAPL remediation challenge: is there a case for source depletion? National Service Center for Environmental Publications (NSCEP), p 112. https://nepis.epa.gov

USEPA (2015) Technical note: light non-aqueous phase liquid assessment and remediation. NSW Environment Protection Authority (EPA), Sydney

Voltattomi N, Sciarra A, Caramanna G, Cinti D, Pizzino L, Quattrocchi F (2009) Gas geochemistry of natural analogues for the studies of geological CO 2 sequestration. Appl Geochem 24:1339-1346. https://doi.org/10.1016/j.apgeochem.2009.04.026

Walia V, Su TC, Fu CC, Yang TF (2005) Spatial variations of radon and helium concentrations in soil-gas across the Shan-Chiao fault, Northern Taiwan. Radiat Meas 40:513-516. https://doi.org/10. 1016/j.radmeas.2005.04.011

Yang TF, Chou CY, Chen C-H, Chyi LL, Jiang JH (2003) Exhalation of radon and its carrier gases in SW Taiwan. Radiat Meas 36:425-429. https://doi.org/10.1016/S1350-4487(03)00164-1

Yoon YY, Koh DC, Lee KY, Cho SY, Yang JH, Lee KK (2013) Using $222 \mathrm{Rn}$ as a naturally occurring tracer to estimate NAPL contamination in an aquifer. Appl Radiat Isot 81:233-237. https://doi.org/10. 1016/j.apradiso.2013.03.061

Zavodska L, Kosorinova E, Scerbakova L, Lesny J (2008) Environmental chemistry of uranium. HV SSN 1418-7108 HEJ Manuser No ENV081221-A, 1-18. http://heja.szif.hu/ 